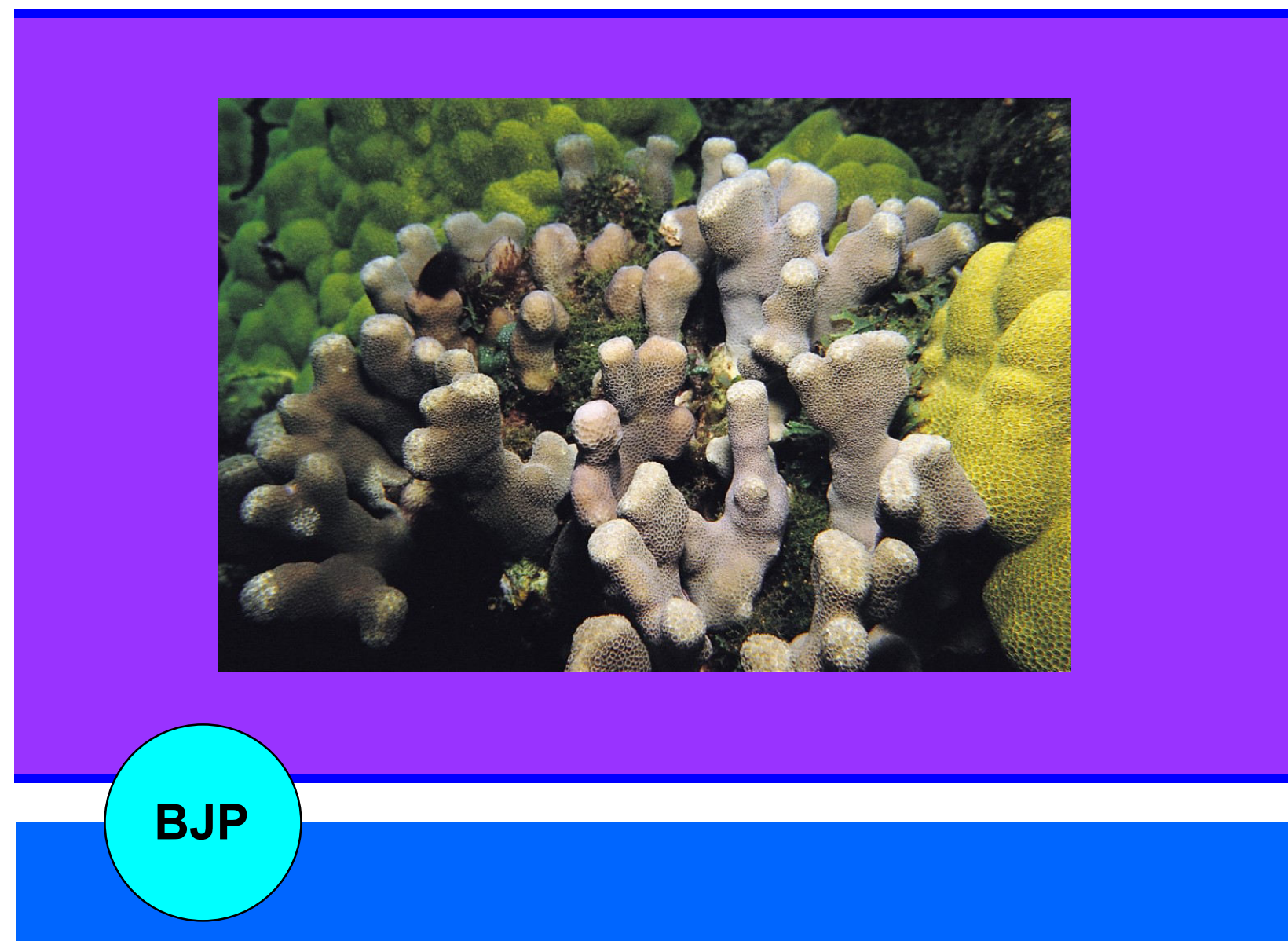

Bangladesh Journal of Pharmacology

Research Article

Screening for antibacterial, antifungal and cytotoxic agents in three hard coral species from Persian Gulf 


\title{
Screening for antibacterial, antifungal and cytotoxic agents in three hard coral species from Persian Gulf
}

\author{
Flora Mohammadizadeh1, Majid Afkhami2, Maryam Ehsanpour2, Amirhoushang Bahri1, \\ and Habib Masihi Taziani1
}

${ }^{1}$ Islamic Azad University, Bandar Abbas Branch, P.O.Box:79159-1311, Bandar Abbas, Iran; ${ }^{2}$ Young researchers club, Islamic Azad University, Bandar Abbas Branch, P.O.Box:79159-1311, Bandar Abbas, Iran.

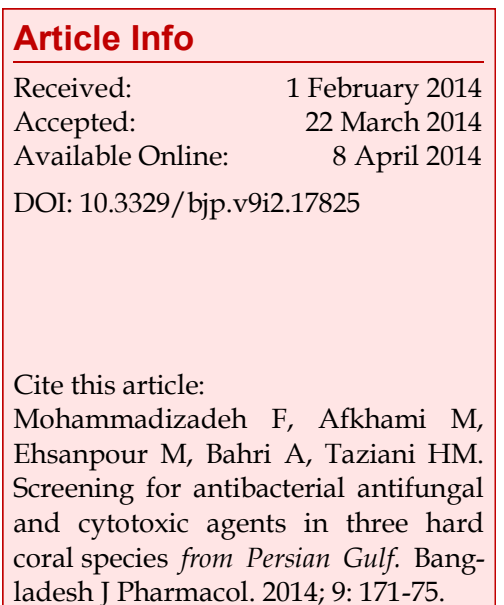

\begin{abstract}
Within the frame of a biodiversity and bioactivity study of marine macro organisms from the Persian Gulf, three hard coral species extracts were investigated for cytotoxic, antibacterial and antifungal activities against five human pathogenic microorganisms. All concentrations of extracts from three hard corals showed no antifungal activity towards the tested strains. In antibacterial assays the hard coral extracts showed significant activity solely against Staphylococcus aureus with MICs ranging from 3 to $9 \mu \mathrm{g} / \mathrm{mL}$. The highest antibacterial activity was found in the aqueous methanol extract of Porites compressa with an inhibition zone of $22 \mathrm{~mm}$ against Staphylococcus aureus at $18 \mu \mathrm{g} / \mathrm{mL}$ extract concentration. It is important for future research to concentrate on finding the mechanisms employed by corals to defend themselves against invasion, the mechanism of infections and the type of chemical compounds in coral extracts that inhibit antibacterial growth or proliferation in underexplored areas such as the Persian Gulf.
\end{abstract}

\section{Introduction}

Hard corals are sessile organisms, then the question will arise; how to do these delicate looking simple creatures protected themselves from predators and pathogens in the marine environment? While answering these interesting ecological questions, researchers found that marine organisms have defense chemical weapons (secondary metabolites) for their protection. Drugs from marine sources are an area, which offers an unprecedented opportunity for their pharmacological exploration and hence have received great attention during recent years for natural product chemistry, a promising area of study. Secondary metabolites produc -ed in marine organisms could be the source of bioactive substances and useful in modeling compounds for drugs (Bhosale et al., 1999). Some of these components were commercialized and reached the market, i.e. the antiviral agent vidarabin (Ara-A), or the antitumor agents cytarabin (Ara-C), ecteinascidin 743 $\left(\right.$ Yondelis $^{\circledR}$ ) and eribulin (Halaven ${ }^{\circledR}$ ).

Given the global deterioration of coral reef ecosystems through climate change and disease outbreaks (Bruno and Selig, 2007), understanding the community ecology and function of coral-associated microbial communities has become increasingly important.

In our ongoing program to monitor and investigate the biodiversity and bioactivity of marine macro organisms from the Persian Gulf we studied the three hard coral species. Usually these species are not overgrown by other macro- or microorganisms. Based on this observation it was hypothesized that these sessile organisms protect themselves by secretion of potent antibiotics or toxins.

In this study, we describe the first report about the screening of aqueous and organic extracts of three hard 
coral species collected from the Persian Gulf.

\section{Materials and Methods}

Sampling and identification: Three species of hard corals were collected using SCUBA diving from Hendurabi Island (26 $\left.46^{\circ} 44^{\prime \prime} \mathrm{N} 53^{\circ} 37^{\prime} 2^{\prime \prime} \mathrm{E}\right)$ in the Persian Gulf in 2011 at depths of 5-15 m. Each sample was cut into small pieces and then immediately frozen and maintained at $-20^{\circ} \mathrm{C}$ Prior to extraction. Information on the organism, the place of collection, date of collection and depth were recorded. Coral species identification was carried out using available references (Veron, 2000).

Extraction: The frozen samples were freeze-dried, macerated with dry ice $\left(\mathrm{CO}_{2}\right)$ by a blender and soaked overnight in distilled water. The supernatants were then removed, centrifuged at 10,000 rpm, filtered and collected. The collected water extracts were freeze-dried (aqueous extract). The insoluble solid materials were then successively extracted with ethyl acetate, methanol and water-methanol $(50 \%)$ successively by percolation (72 hours for each solvent) at room temperature. The organic extracts were combined and the solvent removed by rotary evaporation at no more than $40^{\circ} \mathrm{C}$ to avoid degradation of compounds. All crude extracts were kept at $-20^{\circ} \mathrm{C}$ until further processing (Mohammadizadeh et al., 2013a).

Assay of cytotoxicity effect: Cytotoxic activity of extracts was determined by Brine-Shrimp Lethality assay (BSA) as described by Meyer et al. (1982). Simple zoological organism (Artemia salina) was used as a convenient monitor for the screening. The cysts of the brine shrimp hatched in artificial seawater (3.8\% $\mathrm{NaCl}$ solution) for 48 hours to mature shrimp called nauplii. Different concentrations of each extract dissolved in normal saline were obtained by serial dilution. Four concentrations of each extract were prepared with 10, 100, 500 and 1000 $\mu \mathrm{g} / \mathrm{mL}$. Twenty naupliis were added to each concentration of the extracts in 24 well chamber slides. Number of nauplii alive noted after 24 hours. The mortality end point of the bioassay was determined as the absence of controlled forward motion during $30 \mathrm{sec}$ of observation. Seawater and berberine hydrochloride $\left(\mathrm{LC}_{50}=26 \mu \mathrm{g} /\right.$
$\mathrm{mL}$ ) were used as controls. Lethality percentage was determined and $\mathrm{LC}_{50}$ calculated based on Probit Analysis with $95 \%$ of confidence interval using computer software "BioStat-2007".

Antibacterial and antifungal assay: The antibacterial and antifungal activities of $P$. harrisoni, $P$. compress and $P$. daedatea extracts were assessed against Escherichia coli (ATCC 1763), Staphylococcus aureus (ATCC 25923), Pseudomonas aeruginosa (ATCC 25853) Candida albicans (ATCC 10231) and Aspergillus niger (ATCC 16404) by the disc diffusion susceptibility method (Ghohari et al., 2010). The extracts were tested in the lowest concentration at which no growth was observed, recorded as minimum inhibitory concentration (MIC). Culture media with different concentrations of gentamicin and fluconazole were used as positive controls. Antibacterial and antifungal assays were performed in triplicates.

\section{Results}

P. harrisoi and P. compressa belong to Phylum Cnidaria, class Anthozoa, and order Scleractina, family Poritidea. P. compressa, finger coral or hump coral is a species of marine stony coral. It is found growing on coral reefs and in shallow lagoons in tropical parts of the Indian and Pacific Oceans. It is generally pale brown or grey. In shallow water it resembles a knobbly boulder but in deeper water it is more columnar (Flora and Ely, 2003). $P$. harrisoi is found in shallow fringing reefs, generally to depths of $15 \mathrm{~m}$. It prefers areas of low exposure, and tolerates sedimented conditions well (Sheppard and Sheppard, 1991). Platygyra daedatea or brain coral are from Faviidea family, widely distributed throughout the Indo-Pacific, from the Red Sea to the Marshall Islands. Living colonies are in variable colors, usually brightly colored, such as brown walls with green valleys. In habitats where light is reduced, the colonies are darker. This is the most commonly of several massive (mound-forming) species with a surface that resembles the maze-like pattern of a mammal brain. Colonies from well illuminated reefs exposed to wave action tend to be spherical (Veron, 2000). These corals are found in Hendurabi Island in the north coast of the Persian Gulf.

\section{Table I}

Antimicrobial activity of hard corals species $P$. compress $a(\mathbf{P c})$ and $P$. daedatea $(\mathbf{P d})$ extracts from Persian Gulf

\begin{tabular}{|c|c|c|c|c|c|c|c|c|}
\hline \multirow[t]{2}{*}{ Organism } & \multirow[t]{2}{*}{ Extract } & \multicolumn{7}{|c|}{ Zone of inhibition (mm) } \\
\hline & & $\begin{array}{c}\mathrm{MIC} \\
\mu \mathrm{g} / \mathrm{mL}\end{array}$ & $\begin{array}{c}4 \\
\mu \mathrm{g} / \mathrm{mL}\end{array}$ & $\begin{array}{c}8 \\
\mu \mathrm{g} / \mathrm{mL}\end{array}$ & $\begin{array}{c}10 \\
\mu \mathrm{g} / \mathrm{mL}\end{array}$ & $\begin{array}{c}14 \\
\mu \mathrm{g} / \mathrm{mL}\end{array}$ & $\begin{array}{c}16 \\
\mu \mathrm{g} / \mathrm{mL}\end{array}$ & $\begin{array}{c}18 \\
\mu \mathrm{g} / \mathrm{mL}\end{array}$ \\
\hline S. aureus & Pd (methanol) & 3 & 6 & 8 & 13 & 13 & 14 & 14 \\
\hline S. aureus & Pd (ethyl acetate) & 9 & 0 & 0 & 10 & 15 & 15 & 16 \\
\hline S. aureus & Pc (methanol-water) & 9 & 0 & 0 & 18 & 20 & 21 & 22 \\
\hline S. aureus & Pc (ethyl acetate) & 3 & 8 & 10 & 11 & 12.5 & 14 & 15 \\
\hline
\end{tabular}




\begin{tabular}{|c|c|c|c|c|c|c|c|c|c|c|}
\hline \multicolumn{11}{|c|}{ Table II } \\
\hline \multicolumn{11}{|c|}{$\begin{array}{c}\text { Cytotoxic activity of hard coral species, Porites harrisoi }(\mathrm{Ph}), \text { Porites compressa }(\mathrm{Pc}) \text { and Platygyra } \\
\text { daedatea }(\mathbf{P d}) \text { extracts from the Persian Gulf }\end{array}$} \\
\hline \multirow[t]{2}{*}{ Extract } & \multirow[t]{2}{*}{$\begin{array}{l}\text { Dose } \\
(\mu \mathrm{g} / \mathrm{mL})\end{array}$} & \multirow[t]{2}{*}{$\begin{array}{r}\text { Log } \\
\text { dose }\end{array}$} & \multirow[t]{2}{*}{ Total } & \multirow[t]{2}{*}{ Alive } & \multirow[t]{2}{*}{ Death } & \multirow[t]{2}{*}{$\begin{array}{l}\text { Lethalit } \\
\mathrm{y}(\%)\end{array}$} & \multirow[t]{2}{*}{$\mathrm{LC}_{50}$} & \multirow[t]{2}{*}{$\begin{array}{l}\text { Chi- } \\
\text { square }\end{array}$} & \multicolumn{2}{|c|}{$\begin{array}{c}\text { 95\% Confidence } \\
\text { Limits }\end{array}$} \\
\hline & & & & & & & & & Lower & Upper \\
\hline \multirow{4}{*}{$\begin{array}{l}\text { PH } \\
\text { (methanol) }\end{array}$} & 10 & 1 & 20 & 18 & 2 & 10 & \multirow[t]{4}{*}{363.3} & \multirow[t]{4}{*}{3.1} & \multirow[t]{4}{*}{181.6} & \multirow[t]{4}{*}{889.5} \\
\hline & 100 & 2 & 20 & 17 & 3 & 15 & & & & \\
\hline & 500 & 2.7 & 20 & 9 & 11 & 55 & & & & \\
\hline & 1000 & 3 & 20 & 5 & 15 & 75 & & & & \\
\hline \multirow{4}{*}{$\begin{array}{l}\text { PH (ethyl- } \\
\text { acetate) }\end{array}$} & 10 & 1 & 20 & 20 & 0 & 0 & \multirow[t]{4}{*}{$>1000$} & \multirow[t]{4}{*}{ - } & \multirow[t]{4}{*}{-} & \multirow[t]{4}{*}{ - } \\
\hline & 100 & 2 & 20 & 20 & 0 & 0 & & & & \\
\hline & 500 & 2.7 & 20 & 19 & 1 & 5 & & & & \\
\hline & 1000 & 3 & 20 & 16 & 4 & 20 & & & & \\
\hline \multirow{4}{*}{$\begin{array}{l}\text { PC } \\
\text { (methanol) }\end{array}$} & 10 & 1 & 20 & 19 & 1 & 5 & \multirow[t]{4}{*}{356.7} & \multirow[t]{4}{*}{0.8} & \multirow[t]{4}{*}{190.5} & \multirow[t]{4}{*}{750.8} \\
\hline & 100 & 2 & 20 & 16 & 4 & 20 & & & & \\
\hline & 500 & 2.7 & 20 & 9 & 11 & 55 & & & & \\
\hline & 1000 & 3 & 20 & 5 & 15 & 75 & & & & \\
\hline \multirow{4}{*}{$\begin{array}{l}\text { PC (water- } \\
\text { methanol) }\end{array}$} & 10 & 1 & 20 & 19 & 1 & 5 & \multirow[t]{4}{*}{$>1000$} & \multirow[t]{4}{*}{0.9} & \multirow[t]{4}{*}{-} & \multirow[t]{4}{*}{-} \\
\hline & 100 & 2 & 20 & 19 & 1 & 5 & & & & \\
\hline & 500 & 2.7 & 20 & 17 & 3 & 15 & & & & \\
\hline & 1000 & 3 & 20 & 15 & 5 & 25 & & & & \\
\hline & 10 & 1 & 20 & 20 & 0 & 0 & $>1000$ & 0.5 & - & - \\
\hline (methanol) & 100 & 2 & 20 & 18 & 2 & 10 & & & & \\
\hline & 500 & 2.7 & 20 & 17 & 3 & 15 & & & & \\
\hline & 1000 & 3 & 20 & 14 & 6 & 30 & & & & \\
\hline
\end{tabular}

Table I summarizes the biological activity of methanol, water-methanol and ethyl acetate extracts. All concentrations of extracts from three hard corals showed no antifungal activity towards the tested strains at the highest concentration tested, which was well below the levels that demonstrated cytotoxicity. In antibacterial assays the hard coral extracts showed significant activity solely against $S$. aureus with MICs ranging from 3 to $9 \mu \mathrm{g} / \mathrm{mL}$. The highest antibacterial activity was found in $P$. compressa $\left(\mathrm{H}_{2} \mathrm{O} / \mathrm{MeOH}\right)$ with an inhibition zone of $22 \mathrm{~mm}$ against $S$. aureus at $18 \mu \mathrm{g} / \mathrm{mL}$ extract concentration. Methanol extracts from $P$. harrisoi and $P$. compressa exhibited cytotoxic activities (Table II). Here we must state that at the relevant concentration $10 \mu \mathrm{g} /$ $\mathrm{mL}$ and maybe $100 \mu \mathrm{g} / \mathrm{mL}$ nearly no toxicity is given (only 0-20\% lethality).

\section{Discussion}

The protective mechanism of coral probiotic bacteria is proposed to include antibacterial activity, and to date there have been a number of studies which demonstrated that corals and their associated bacteria possess such properties (Kelman et al., 2006; Ritchie, 2006).

On the other hand, infectious diseases represent a serious public health problem and they remain the major cause of death throughout the world (WHO, 1998). Currently, there is a problem of microbial drug resistance and an increase of opportunistic infections due to a growth in immunocompromised population such as organ transplant recipients and HIV patients. These problems coupled with the toxicity effect of continued use of several antifungal drugs (Giordani et al., 2001) highlights the need to search for new drugs to treat opportunistic fungal infections (Fostel and Lartey, 2000). Marine organisms possess a glyocproteinaceous film which favors colonization by bacteria, fungi, diatoms, protozoa and other microorganisms (Hellio et al., 2000). Sessile Marine organisms such as holothurians, sea urchins and hard corals are therefore also susceptible to microbial invasion. Although holothurians are known to contain triterpene glycosides, which show antifungal activity, fungi can still be isolated from these organisms. Cladosporium brevicompactum and C. sphaerospermum are common in the holothuroids' coelom. Cladosporium spp., Aspergillus spp. and Penicllium spp. were found on the body surface of the holothurians (Pivkin, 2000). Antifungal, antimicrobial and cytotoxic affects of two sea cucumber species (H. Leucospilota and H. scabra) extractions from different solvent were recorded from Persian Gulf (Mohammadizadeh et al., 2013a, b). This is one of the first attempts to investigate the biological activity of corals in the Persian Gulf.

As shown in Table I, methanolic, ethyl acetate and water methanolic extracts from $P$. compressa and $P$. daedatea have indicated antibacterial activity against $S$. aureus. It is noteworthy to mention that a co-linearity between the applied concentration and the observed antibacterial is only given only for the range 4-15 $\mu \mathrm{g} /$ $\mathrm{mL}$. A further increase in concentration above $16 \mu \mathrm{g} /$ 
$\mathrm{mL}$ does not result in an enhancement of the zone of inhibition anymore. This possibly points to a restricted water-solubility or a restricted diffusion of the bioactive components into the agar.

Whilst it is likely that the presence of some bacterial species on a coral can affect the abundance of others-a theory supported by a metagenomic analysis on the coral Porites astreoides-in which coral associated bacteria were shown to carry genes for 'waging chemical warfare' (Wegley et al., 2007), it is not known to what extent such interactions are governed by the bacteria themselves or mediated by the coral host. Extracts from scleractinian corals have been shown to contain antimicrobial compounds (Geffen and Rosenberg, 2005), but antimicrobial compounds have also been reported in coral-associated bacteria (Nissimov and Munn, 2007). Thus, antimicrobial activity is likely to arise from both microbial and host sources.

Change in the environment or the health status of the coral allows for changes to the microbial community. This also may suggest that production and secretion of antimicrobial compounds by mucus-associated bacteria is part of the scleractinian coral's defense strategy against pathogens (Rohwer et al., 2002; Ritchie, 2006).

In several studies the antibacterial activity of hard corals has been analyzed. Koh (1971) showed the alcohol extract of a large percentage of coral samples had antibacterial activity against a number of heterotrophic bacteria and cyanobacteria, while results obtained by Kim (1994) demonstrated antibacterial activity for both polar and non-polar (coral-derived) fractions with higher activity associated with non-polar fractions. Rohwer et al. (2002) hypothesized that the microbial community found on a coral's surface may play a role in the coral's defense mechanism, possibly by occupying niches or through the production of antimicrobial metabolites. Ritchie (2006) found antibacterial activity among the microbial community associated with the mucus of healthy corals. Antimicrobial activity was found mostly among extracts obtained with non-polar rather than hydrophilic solvents (Miroslav et al., 2011; Kreitlow, 1999). Nissimov et al. (2009) found, antibacterial properties from coral mucus. Antibacterial activity in extracts of this hard species suggests a possible ecological function for their secondary metabolites. The antibacterial property of the hard corals extracts reveals that they are strong enough to be less affected by bacterial organisms than the fungal. According to Kelman et al. (2006), soft coral extracts were found to be more active than hard coral extracts. The authors also suggested that there are different mechanisms of antimicrobial activity against pathogens involved in scleractinian corals.

S. aureus is still a relevant pathogen in the medical area; therefore chemical investigations from new resources are ongoing. It is important for future research to concentrate on finding the mechanisms of bacterial infection and the type of chemical compound in this hard coral species extracts that inhibit bacterial growth or proliferation.

Fungal associations with hard corals are better known and are usually manifested in the form of diseases. Twelve genera of deuteromycetous fungi have been isolated from hard corals and hydrocorals (Kendrick et al., 1982). In this study, it was shown that Porites harrisoni, Porites compressa and Platygyra daedatea extracts were not effective against any of the fungal species tested even at a concentration of $18 \mu \mathrm{g} / \mathrm{mL}$. They did not inhibit fungal growth at the highest tested extract concentration as well. This shows that the amount of extract present in the tissues of this species bore no relationship with its antifungal activity. It seems there are different fungal spectrums in the sea which is pathogenic for these hard corals or it would possibly harm endosymbiontic fungi species in this area. Otherwise Bak and Lanne (1987) observed black bands made up of high concentrations of a dark fungus in Porites. The fungus, Scolecobasidium sp. was found to cause necrotic patches on corals from the Andaman Islands (Raghukumar and Raghukumar, 1991). Le Campion-Alsumard et al. (1995) have also found fungi to bore through the skeleton of live Porites. Fungi are able to bore through the skeleton of hard corals by chemical dissolution and they are also able to utilize the organic matrix of coral skeletons (Glynn, 1997).

In this study the highest cytotoxic activity was obtained from methanolic extracts. The highest cytotoxic effect on methanol extract with LC $_{50}$ values about $356.3 \mu \mathrm{g} /$ $\mathrm{mL}$ from $P$. compressa followed by the methanol extract from $P$. harrisoi with $\mathrm{LC}_{50}$ values about $363.3 \mu \mathrm{g} / \mathrm{mL}$. The positive results have been recorded in the methanolic extraction and it shows that it is a good solvent system to the solubility of bioactive compounds present in this hard coral species. The values were not as effective as our previous study in sea cucumbers $(H$. leocuspilota and H. scabra) (Mohammadizadeh et al., 2013a, b). Wang and coworkers (2009) reported powerful cytotoxic activities' from the soft coral Lobophytum michaelae. Hard corals are harder than soft corals and therefore less fish attacked, so it appears that in our study powerful cytotoxic activities were not present maybe due to the unspecific compounds obtained. Thus, further partitioning of different extracts need to be carried out to reveal the potentially active compounds. Marine environments, including tropical and sub-tropical coral reefs, have served as a source for novel natural products for decades. It may be that corals, and in particular their associated microorganisms, are a potential new source for antibacterial and other metabolites that could serve as biomedical agents with relevance to human health in a manner similar to bioactive compounds derived from marine sponges. 
It is important for future research to concentrate on finding the mechanisms employed by corals to defend themselves against invasion, the mechanism of infections and the type of chemical compound in coral extracts that inhibit bacterial growth or proliferation in underexplored areas such as Persian Gulf.

\section{Acknowledgement}

We thank Prof. Harald Gross from Pharmaceutical Biology Institute, University of Tübingen, Germany for his scientific assistances. The authors wish to acknowledge the Bandar Abass branch Islamic Azad University for financial Support and cooperation in implementing this project.

\section{References}

Bak RPM, Lanne RWPM. Annual black bands in skeletons of reef corals (Scleractinia). Mar Ecol Prog Ser. 1987; 38: 16975 .

Bhosale SH, Jagtap TG, Naik CG. Antifungal activity of some marine organisms from India against food spaelage Aspergillus strains. Mycopathologia 1999; 147: 133-38.

Bruno JF, Selig ER. Regional decline of coral cover in the IndoPacific: Timing, extent, and subregional comparisons. PLoS ONE. 2007; 2: e711.

Flora CJ, Ely PS. Surface growth rings of Porites lutea Microatolls accurately track their annual growth. Northwest Sci. 2003; 77: 237-45.

Fostel J, Lartey P. Emerging novel antifungal agents. Drug Disc Today. 2000; 5: 25-32.

Geffen Y, Rosenberg E. Stress-induced rapid release of antibacterials by scleractinian corals. Mar Biol. 2005; 146: 931 -35 .

Giordani R, Trebaux J, Masi M, Regli P. Enhanced antifungal activity of ketoconazole by Euphorbia characias latex against Candida albicans. J Ethnopharmacol. 2001; 78: 1-5.

Glynn PW. Bioerosion and coral reef growth: A dynamic balance. In: Life and death of coral reefs. Irkeland C. (ed.). New York, Chapman \& Hall, 1997, pp 68-95.

Hadacek F, Greger H. Testing of antifungal natural products: methodologies, comparability of results and assay choice. Phytochem Anal. 2000; 11: 137-47.

Hellio C, Bremer G, Pons AM, Le Gal Y, Bourgougnon N. Inhibition of the development of microorganisms (bacteria and fungi) by extracts of marine algae from Brittany, France. Appl Microbiol Biotechnol. 2000; 54: 543-49.

Kendrick B, Risk MJ, Michaelides J, Bergman K. Amphibious microborers: Bioeroding fungi isolated from live corals. Bull Mar Sci. 1982; 32: 862-67.

Kim K. Antimicrobial activity in gorgonian corals (Coelentrate, Octocorallia). Coral Reefs, 1994; 13: 75-80.
Koh EGL. Do scleractinian corals engage in chemical warfare against microbes? J Chem Ecol. 1997; 23: 379-98.

Kreitlow S, Mundt S, Lindequist U. Cyanobacteria: A potential source of new biologically active substances. J Biotechnol. 1999; 70: 61-63.

Le Campion-Alsumard T, Golubic S, Priess K. Fungi in corals: Symbiosis or disease? Interactions between polyps and fungi causes pearl-like skeleton biomineralization. Mar Ecol Prog Ser. 1995; 117: 137-47.

Miroslav G, Longin T, Stanić KD, Miller AW, Richardson LL. Antibacterial activity of marine and black band disease Cyanobacteria against coral-associated bacteria. Mar Drugs, 2011; 9: 2089-2105.

Mohammadizadeh F, Ehsanpour M, Afkhami M, Khazaali A, Mokhlesi A, Montazeri S, Bahri A. Antibacterial, antifungal and cytotoxic effects of a sea cucumber Holothuria Leucospilata, from North coastal of the Persian Gulf. Marine Biol Assoc J. 2013; 1-5.

Mohammadizadeh F, Ehsanpour M, Afkhami M, Mokhlesi A, Montazeri S. Evaluation of antibacterial, antifungal and cytotoxic effects of Holothuria scabra from North Coast of the Persian Gulf. J De Mycologie Médicale. 2013.

Nissimov JRE, Munn CB. Antimicrobial properties of resident coral mucus bacteria of Oculina patagonica. FEMS Microbial Lett. 2009; 292: 210-15.

Pivkin MV. Filamentous fungi associated with holothurians from the Sea of Japan, off the Primorye Coast of Russia. Biol Bull. 2000; 198: 101-09.

Raghukumar C, Raghukumar S. Fungal invasion of massive corals. PSZNI: Mar Ecol. 1991; 12: 251-60.

Ritchie KB. Regulation of microbial populations by coral surface mucus and mucus-associated bacteria. Mar Ecol Prog Ser. 2006; 322: 1-14.

Rohwer F, Seguritan V, Azam F, Knowlton N. Diversity and distribution of coral-associated bacteria. Mar Ecol Prog Ser. 2002; 243: 1-10.

Sheppard A, Fenner D, Edwards A, Abrar M. Ochavillo D. Porites harrisoni. 2008. In: IUCN Red List of Threatened Species.

Veron JEN. Corals of the world. Vol 3. Australia, Australian Institute of Marine Science and CRR Qld. Pty. Ltd. 2000, p 490.

Wang SK, Duh CY, Wu YC, Wang Y, Cheng MC, Soong K, Fang LS. Cytotoxic cembranolides from the soft coral Lobophytum michaelae. J Nat Prod. 2009; 72: 324.

Wegley L, Edwards R, Rodriguez-Brito B, Liu H, Rohwer F. Metagenomic analysis of the microbial community associated with the coral Porites astreoides. Environ Microbiol. 2007; 9: 2707-19.

World Health Organization. The World Health report. Life in the 21st century: A vision for all. Geneva, World Health Organization, 1998, pp 39-60.

Author Info

Flora Mohammadizadeh (Principal contact)

, e-mail: fmohammadi13@gmail.com 